\title{
Australian Journal of Crop Science \\ Performances of low frequency rubber tapping system with rainguard in high rainfall area in Myanmar
}

\author{
Zar Ni Zaw ${ }^{1 *}$, Sayan Sdoodee ${ }^{1}$, Regis Lacote $^{2}$ \\ ${ }^{1}$ Program of Natural Rubber Production, Technology and Management Program, Natural Resources Faculty, \\ Prince of Songkla University, Songkhla 90112, Thailand \\ ${ }^{2}$ CIRAD, UPR Tree Crop-based Systems, HRPP, R\&D, Kasetsart University, Bangkok, 10900, Thailand
}

*Corresponding author: Email: spszarni@gmail.com

\begin{abstract}
In Myanmar, natural rubber (Hevea brasiliensis) is mainly grown in the southern part of the country, where the rainfall is too high leading to suspension of tapping in the rainy season and intensive tapping after the rainy season. Rubber farmers face problems of uneven distribution of tapping days, low tapper productivity, high tapping cost, and shorter economical lifespan of the trees. Hence, a study was carried out to address the problems by conducting an on-farm experiment to assess performances of low frequency rubber tapping system (LFRTS) with rainguard in the area. Five treatments: $\left(\mathrm{T}_{1}\right) \mathrm{S} / 2 \mathrm{~d} 2$ (no tapping in the rainy season); ( $\left.\mathrm{T}_{2}\right) \mathrm{S} / 22 \mathrm{~d} 3$ (no tapping in the rainy season); ( $\left.\mathrm{T}_{3}\right) \mathrm{S} / 2(\mathrm{RG}) \mathrm{d} 2$ (tapping with rainguard in the rainy season); ( $\mathrm{T}_{4}$ ) $\mathrm{S} / 2 \mathrm{~d} 3 \mathrm{ET} 2.5 \% \mathrm{~Pa}(1) 3 / \mathrm{y}(\mathrm{m})$ (tapping without rainguard in the rainy season); ( $\mathrm{T}_{5}$ ) S/2 (RG) d3 ET2.5\% Pa (1) 3/y (m) (tapping with rainguard in the rainy season) were evaluated. The cumulative yield in kilogram per tree of $\mathrm{T}_{5}$ during the study period was comparable to that of $\mathrm{T}_{1}$, while its daily yield in gram per tapping per tree was $23 \%$ and $30 \%$ higher than that of $\mathrm{T}_{1}$ and $\mathrm{T}_{2}$, respectively. Bark consumption of $\mathrm{T}_{5}$ was $16 \%$ and $39 \%$ lower than that of $\mathrm{T}_{1}$ and $\mathrm{T}_{2}$, respectively. $\mathrm{T}_{5}$ needed only $67 \%$ of tapper requirement by $\mathrm{d} 2$ frequency tapping. Tapping costs of $\mathrm{T}_{5}$ were $17 \%$ lower than those of conventional tapping system, $\mathrm{T}_{1}$. The study suggested that LFRTS with rainguard could be implemented to address the problems of the farmers in the area.
\end{abstract}

Keywords: bark consumption; low frequency rubber tapping system; rainguard; tapping cost; tapper productivity; tapper requirement.

Abbreviations: $2 \mathrm{~d} 3$ _ two tappings in three days; $\mathrm{BO}-2_{-}$virgin bark at second basal panel; $\mathrm{d} 2$ _ alternate tapping; $\mathrm{d} 3$ _third daily tapping; ET_ethephon stimulation; LFRTS_ low frequency rubber tapping system; Pa_panel application; RG_rainguard; S/2_ half spiral cut (length of tapping cut)

\section{Introduction}

Myanmar is one of natural rubber producing countries which contributed 1.6 percent of the world rubber production in 2015. In Myanmar, rubber is traditionally planted in the southern part of the country. Majority of the planted area is owned by smallholders who mainly depend on rubber growing for their livelihoods as their main income. Although the area is the major rubber growing area in the country, there are many obstacles including low productivity which was only $770 \mathrm{~kg} / \mathrm{ha} / \mathrm{yr}$ in 2014 as a major weakness (Myint, 2015). One reason of the low productivity is limitation of the number of tapping days. Normally, in that area, tapping is suspended completely in three and half to four months in the rainy season due to heavy and continuous raining with 4,500 $\mathrm{mm}$ of average annual rainfall which starts from June to September. Therefore, around 100-120 working days of tapping are lost during the rainy season without any production from the rubber farms (Zaw, 2012). Consequently, the farmers harvest intensively after the rainy season, from October to May without resting in wintering period although the normal inherent yield is very low in this period. Suspending the tapping in the rainy season causes problems of unevenly distributed tapping days and lack of work for tappers in the rainy season. This leads to shortage of skilled tappers. The practice of high frequency tapping after the rainy season makes lower tapper productivity, higher tapping cost, higher bark consumption and shorter economical life span of the trees.

Since tapping with rainguard in the rainy season increases the number of tapping days by preventing panel wetting and washout (Gan et al., 1985), tapping days can be distributed more evenly. The use of rainguard reduces the problem of seasonal unemployment of rubber tappers (Tillekeratne and Nugawela, 1995) as tapping works can be carried out regularly in the rainy season. During the wintering period, when the yield is too low, tapping should be stopped (Webster and Paardekooper, 1989).

By implementing low frequency rubber tapping systems (LFRTS), rubber yield per tapping per tree could be maximized as it increases the number of days between two successive tappings, notably latex regeneration period, ensure that more latex is regenerated during the period (Serres et al., 1994; Obouayeba et al., 2010; Karunaichamy et al., 2012). However, reduction in tapping frequency reduces cumulative yield per tree. Thus, under LFRTS, yield stimulant must be applied to receive optimum production (Sivakumaran, 1982; Rodrigo et al., 2011). The main effect of stimulation is that of prolonging the duration of latex flow and thus increasing the amount of latex discharged during tapping (Jacob et al., 1989; 
d'Auzac et al., 1997). Implementing LFRTS increases the tapper productivity, which is mainly influenced by increased tapping days with every daily yield in gram per tapping per tree, is an important consideration of rubber farmers to reduce the cost of production under current situation of high labour wages (Vijayakumar et al., 2001). It enables to reduce tapper requirement and addresses the problems of skilled labour shortage (Chan et al., 1983; Hassan et al., 1999; Soumahin et al., 2010), without reduction in level of yield, compared to that of the conventional tapping system. In addition, longer economic lifespan of the tree could be expected under LFRTS because of its lower bark consumption (Vijayakumar et al., 2003; Rodrigo, 2012).

Since the suspension of tapping in the rainy season is the main root of the cause of low productivity, implementing LFRTS with rainguard was assumed to be a solution to address the problems. Therefore, a study was carried out by conducting an on-farm experiment on different tapping systems including LFRTS with rainguard, and interviewing the farmers and tappers in the area.

The objectives of the study were to study the effectiveness of rainguard and yield performances, labour requirement and tapping cost of LFRTS with rainguard in the high rainfall area.

\section{Results and Discussion}

\section{Rainfall distribution and tapping days}

The rainy season started from the middle of May and ended in September in the study area in 2015. Total rainfall was $4028 \mathrm{~mm}$ and the total number of raining days was 125 days during the study period from June 2015 to May 2016. Of the total rainfall, $96 \%$ was recorded during the rainy season. It peaked in July and August with $1521 \mathrm{~mm}$ and $973 \mathrm{~mm}$, respectively (Fig 1).

Figure 2 shows aggregated rainfall during the study period according to three-hourly time patterns. It was found that rainfall peaked in the morning as $36 \%$ of the total rainfall was aggregated between 3:00 am and 9:00 AM when the tapping works are normally carried out. Thus, it is confirmed that the rain really interfere the tapping work. Hence, tapping could not be carried out regularly during the rainy season in the area.

Table 1 shows actual tapping days during the rainy season against targeted tapping days according to the different tapping frequencies. Comparing only $\mathrm{T}_{3}, \mathrm{~T}_{4}$, and $\mathrm{T}_{5}$, which were tapped in the rainy season, number of tapping days of $\mathrm{T}_{4}$ was the lowest, only 22 days. It was found that around 40 and 30 actual tapping days could be extended by rainguard under $\mathrm{d} 2$ and $\mathrm{d} 3$ tapping systems, respectively, during the rainy season. $\mathrm{T}_{5}$ could tap $74 \%$ of targeted tapping days effectively while $\mathrm{T}_{3}$ could meet only $67 \%$ of targeted tapping days despite it had more actual tapping days. It shows that under rainguard tapping, d3 frequency tapping is more efficient than $\mathrm{d} 2$ frequency tapping in terms of tapping days during the rainy season. Yogaratnam (2013) reported that rainguard is necessary to implement an effective LFRT system in India where the annual rainfall is around $4500 \mathrm{~mm}$ and around 140 tapping days are lost each year due to the heavy rain. Sivakumaram et al. (1998) also reported that in Malaysia, rainguard is essential at tapping works as over 70 tapping days and around $500 \mathrm{~kg} / \mathrm{ha} / \mathrm{yr}$ of yield were lost every year due to the rain. As Said et al. (1998) reported, it is found that yield stimulation is more effective under rainguard tapping because tapping panel is dry underneath the rainguard and the yield stimulant could not be washed out by rain.

\section{Rubber yield performance}

During the study period, $\mathrm{T}_{2}$ and $\mathrm{T}_{3}$ had the highest cumulative yield in kilogram per tree $(\mathrm{kg} / \mathrm{t})$ with higher number of tapping days among the treatments (Table 2). It proves that the cumulative yield is directly associated to the number of tapping days. The high number of tapping days of $\mathrm{T}_{3}$ was contributed by the rainguard tapping in the rainy season while that of $T_{2}$ was due to intensive tapping after the rainy season which resulted in the lowest daily yield in gram per tapping per tree. On the other hand, $\mathrm{T}_{5}$ showed its daily yield in gram per tapping per tree $(\mathrm{g} / \mathrm{t} / \mathrm{t})$, was $23 \%$ and $30 \%$ higher than that of $\mathrm{T}_{1}$ and $\mathrm{T}_{2}$. It was contributed by LFRTS with yield stimulation which causes higher yield per tapping. However, the cumulative yield of $T_{5}$ was not the highest but comparable to that of $\mathrm{T}_{1}, \mathrm{~S} / 2 \mathrm{~d} 2$ tapping system. These results confirmed that tapping frequency is negatively correlated to the yield per tapping per tree and positively related to cumulative yield (Obouayeba et al., 2011; Lacote et al., 2014). Thanh et al. (1996) reported that cumulative yield of $\mathrm{d} 3$ was only $93 \%$ of that obtained from $\mathrm{d} 2$ tapping system. However, the rainguard tapping allowed higher number of tapping days resulting in comparable cumulative yield. The result found that using proper yield stimulation with effective rainguard could compensate for the reduction in the cumulative yield due to the higher daily yield of LFRTS.

\section{Bark consumption}

Table 3 shows comparison of bark consumptions among the treatments during the study period. It was apparent that the average bark consumption of $2 \mathrm{~d} 3$ frequency tapping, $\mathrm{T}_{2}$, was the highest with $23 \%$ higher than that of $\mathrm{d} 2$ frequency tapping, $\mathrm{T}_{1}$. However, the average bark consumptions of $\mathrm{d} 3$ frequency tapping, $\mathrm{T}_{4}$ and $\mathrm{T}_{5}$, were lower than that of $\mathrm{T}_{1}(57$ $\%$ and $62 \%$, respectively). $\mathrm{T}_{2}$ and $\mathrm{T}_{3}$ had higher bark consumption ( $123 \%$ and $110 \%$ respectively) than that of $\mathrm{T}_{1}$. It shows that the higher frequency of tapping causes the higher in bark consumption. It is also found in the result that although LFRTS, $\mathrm{T}_{4}$ and $\mathrm{T}_{5}$, consumed the thicker bark shaving per tapping than the other treatments, the total bark consumption of $T_{4}$ and $T_{5}$ during the study period were apparently lower. It replicates the finding by Rodrigo (2012) that although bark shaving per tapping of LFRTS is thicker than that of the conventional tapping, $S / 2 \mathrm{~d} 2$, the effect is marginal compared to overall bark saving. Vijayakuma et al. (2003) reported his finding in India that LFRTS could extend at least four to eight years in the productive lifespan comparing with the conventional tapping system, $\mathrm{S} / 2 \mathrm{~d} 2$. Besides, lower bark consumption causes delaying commencement of tapping on renewed barks resulting longer resting period for the renewed bark generation (Kudaligama et al., 2010). Hence, potential higher yield could be expected from the renewed bark under LFRTS (Vijayakumar et al., 2003; Rodrigo et al., 2012).

\section{Tapper requirement}

$\mathrm{T}_{1}$ and $\mathrm{T}_{3}$ split the trees into two plots and tapped only one plot a day. $T_{2}$ separated its trees into three plots and tapped two plots a day. However, $\mathrm{T}_{4}$ and $\mathrm{T}_{5}$ split the trees into three plots and tapped only one plot a day. Table 4 shows the requirement of tapper of for 4000 trees of rubber field based on 700 trees of task size. 
Table 1. Tappable days in the five treatments in the rainy season (June to September 2015).

\begin{tabular}{|c|c|c|c|c|c|c|c|c|c|c|c|}
\hline \multirow{2}{*}{ Months } & \multirow{2}{*}{ No. of raining days } & \multicolumn{2}{|l|}{$\mathrm{T}_{1}$} & \multicolumn{2}{|l|}{$\mathrm{T}_{2}$} & \multicolumn{2}{|l|}{$T_{3}$} & \multicolumn{2}{|l|}{$\mathrm{T}_{4}$} & \multicolumn{2}{|l|}{$\mathrm{T}_{5}$} \\
\hline & & ATD & TTD & ATD & TTD & ATD & TTD & ATD & TTD & ATD & TTD \\
\hline JUN & 17 & 0 & 0 & 0 & 0 & 7 & 10 & 5 & 7 & 5 & 7 \\
\hline JUL & 29 & 0 & 0 & 0 & 0 & 5 & 16 & 4 & 11 & 4 & 11 \\
\hline AUG & 29 & 0 & 0 & 0 & 0 & 11 & 16 & 5 & 11 & 9 & 11 \\
\hline SEP & 24 & 0 & 0 & 0 & 0 & 15 & 15 & 8 & 10 & 11 & 10 \\
\hline Total days & 99 & 0 & 0 & 0 & 0 & 38 & 57 & 22 & 39 & 29 & 39 \\
\hline Tappable days (\%) & & 0 & & 0 & & $67 \%$ & & $56 \%$ & & $74 \%$ & \\
\hline
\end{tabular}

ATD = Actual Tapping Days; TTD = Targeted Tapping Days

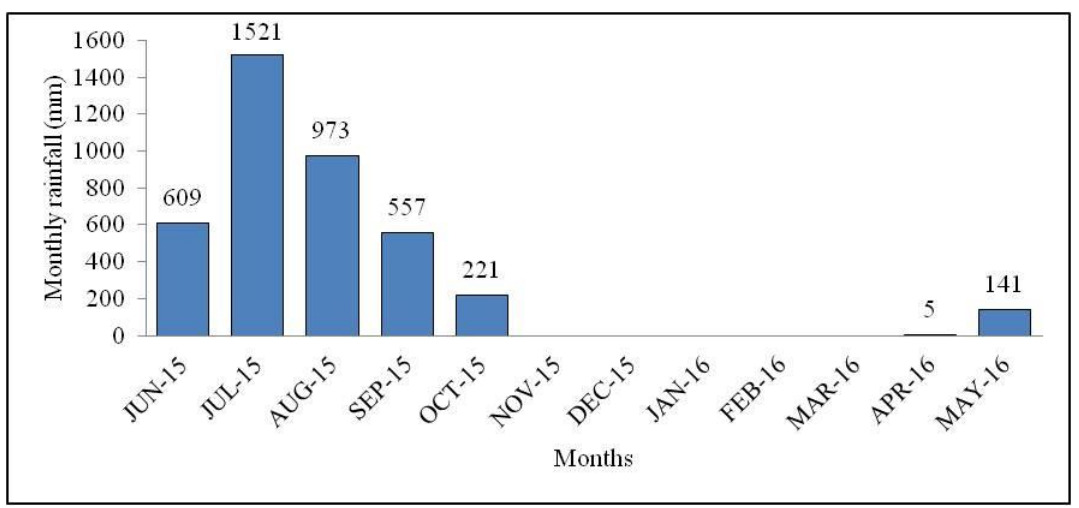

Fig 1. Monthly rainfall from June 2015 to May 2016 at the experiment plot.

Table 2. Daily yield and cumulative yield in the five treatments from June 2015 to May 2016.

\begin{tabular}{lccc}
\hline Treatment & Daily yield $(\mathrm{g} / \mathrm{t} / \mathrm{t})$ & $\begin{array}{c}\text { Cumulative yield per tree } \\
(\mathrm{kg} / \mathrm{t})\end{array}$ & $\begin{array}{c}\text { Number of tapping } \\
\text { days }\end{array}$ \\
\hline $\mathrm{T}_{1}$ & $20.81 \mathrm{~d}$ & $2.39 \mathrm{~b}$ & 114 \\
$\mathrm{~T}_{2}$ & $19.67 \mathrm{e}$ & $2.85 \mathrm{a}$ & 146 \\
$\mathrm{~T}_{3}$ & $22.11 \mathrm{c}$ & $2.96 \mathrm{a}$ & 134 \\
$\mathrm{~T}_{4}$ & $23.24 \mathrm{~b}$ & $2.09 \mathrm{c}$ & 85 \\
$\mathrm{~T}_{5}$ & $25.64 \mathrm{a}$ & $2.4 \mathrm{~b}$ & 93 \\
\hline $\mathrm{CV}$ & 2.48 & 2.85 & \\
\hline
\end{tabular}

Means with different letter in the same column are significantly different at $p \leq 0.05$, computed by Duncan's multiple range Test.

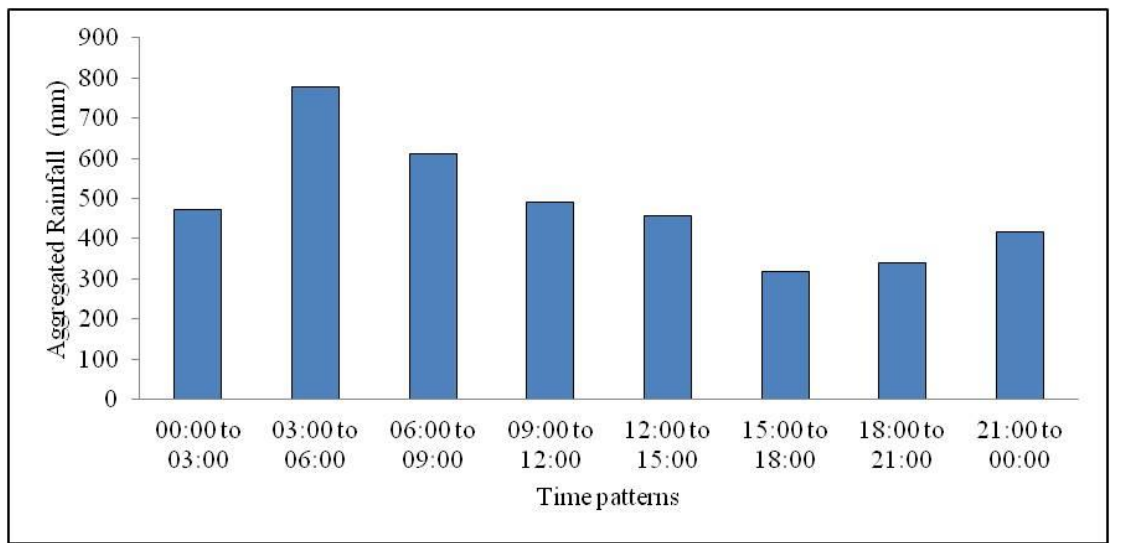

Fig 2. Aggregated rainfall by third hourly time patterns.

Table 3. Bark consumptions in the five treatments from June 2015 to May 2016.

\begin{tabular}{lcc}
\hline Treatment & Average bark consumption $(\mathrm{cm})$ & Monthly bark consumption $(\mathrm{cm})$ \\
\hline T1 & $20.67 \mathrm{c}(100)$ & $2.58(100)$ \\
T2 & $25.52 \mathrm{a}(123)$ & $3.19(123)$ \\
T3 & $22.69 \mathrm{~b}(110)$ & $2.11(82)$ \\
T4 & $15.9 \mathrm{e}(77)$ & $1.48(57)$ \\
T5 & $17.3 \mathrm{~d}(84)$ & $1.61(62)$ \\
\hline
\end{tabular}

Means with different letter in the same column are significantly different at $p \leq 0.05$, computed by Duncan's Multiple range Test. Figures in parenthesis indicate percentage of bark consumption compared to that of $\mathrm{T}_{1}$. 


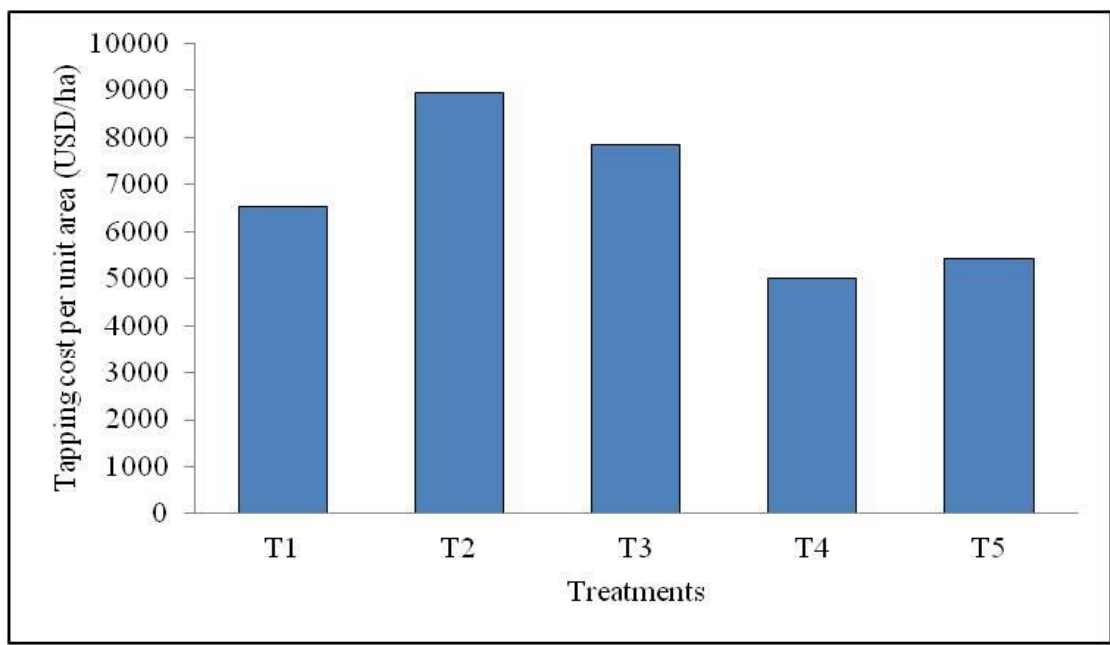

Fig 3. Tapping costs per unit area of the five treatments.

Table 4. Tapper requirements in the five treatments.

\begin{tabular}{lcc}
\hline Treatment & No. of tapped tree per day & No. of tapper required for 4000 tapped trees \\
\hline $\mathrm{T}_{1}$ & 2000 & $3(100)$ \\
$\mathrm{T}_{2}$ & 2667 & $4(133)$ \\
$\mathrm{T}_{3}$ & 2000 & $3(100)$ \\
$\mathrm{T}_{4}$ & 1333 & $2(67)$ \\
$\mathrm{T}_{5}$ & 1333 & $2(67)$ \\
\hline \multicolumn{2}{l}{ Task size $=700$ trees; Number of trees for tapping $=4000$ trees; Figures in parenthesis indicate percentage of tapper requirement compared to that of $\mathrm{T}_{1}}$.
\end{tabular}

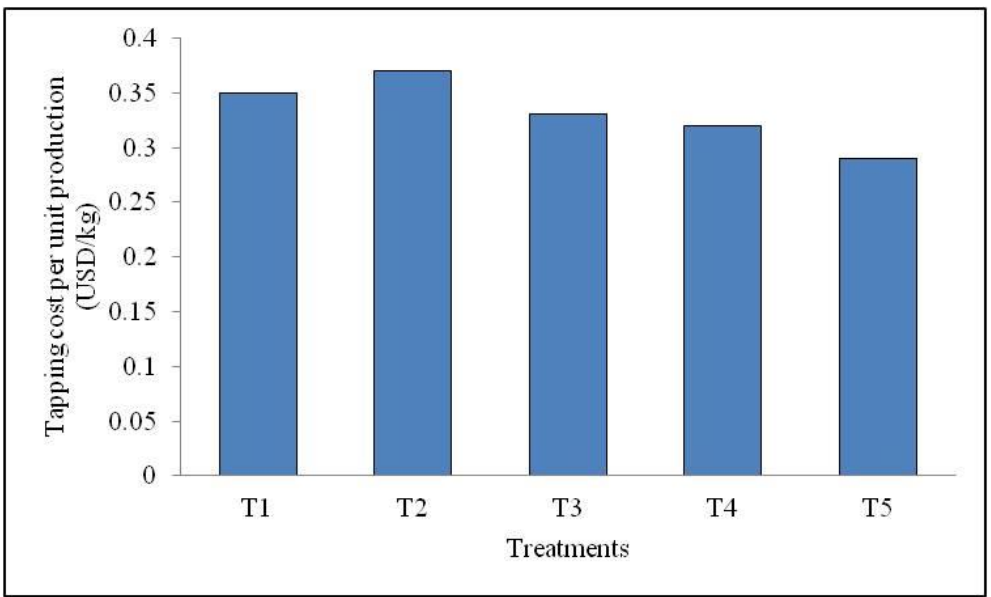

Fig 4. Tapping costs per unit production of the five treatments.

Table 5. Summary of the five treatments.

\begin{tabular}{lccccc}
\hline Treatment & $\begin{array}{c}\text { Length of tapping } \\
\text { cut }\end{array}$ & $\begin{array}{c}\text { Tapping } \\
\text { frequency }\end{array}$ & $\begin{array}{c}\text { Tapping in } \\
\text { the rainy } \\
\text { season }\end{array}$ & $\begin{array}{c}\text { Using } \\
\text { rainguard }\end{array}$ & Stimulation \\
\hline $\mathrm{T}_{1}$ & $\mathrm{~S} / 2$ & $\mathrm{~d} 2$ & No & No & No \\
$\mathrm{T}_{2}$ & $\mathrm{~S} / 2$ & $2 \mathrm{~d} 3$ & No & No & No \\
$\mathrm{T}_{3}$ & $\mathrm{~S} / 2$ & $\mathrm{~d} 2$ & Yes & Yes & No \\
$\mathrm{T}_{4}$ & $\mathrm{~S} / 2$ & $\mathrm{~d} 3$ & Yes & No & ET2.5\% Pa1(1) 3/y (m) \\
$\mathrm{T}_{5}$ & $\mathrm{~S} / 2$ & $\mathrm{~d} 3$ & Yes & Yes & ET2.5\% Pa1(1) 3/y (m) \\
\hline Stimulation times: June, November and December.
\end{tabular}


Since the tapper requirement mainly depends on the number of tapped tree per day, $\mathrm{d} 3$ frequency tappings, $\mathrm{T}_{4}$ and $\mathrm{T}_{5}$, needed only $67 \%$ of tapper requirement by $\mathrm{d} 2$ frequency tapping, $\mathrm{T}_{1}$ and $\mathrm{T}_{3}$. However, the requirement of $2 \mathrm{~d} 3$ frequency tapping, $\mathrm{T}_{2}$, was $33 \%$ higher than that of $\mathrm{d} 2$ frequency tapping (Table 4). It is consistent with the report of Kudaligama et al. (2010) that reduction in tapping frequency from $\mathrm{d} 2$ to $\mathrm{d} 3$ reduced the number of tapper requirement by $33 \%$. LFRTS enables not only reducing the number of tapper requirement but also increasing land-man ratio and tapper productivity (Nugawela et al., 2000; Soumanhin et al., 2010; Mahyao et al., 2014) because under this system, the trees in a certain task get more resting time for latex regeneration, and the tapper could be assigned to tap other tasks in the following two days while the first task is resting. Because of higher tapper productivity under LFRTS, tapper incomes or wages could be increased. As the result, tapping employment would be more competitively attractive and could address problems of skilled tapper shortage (Chan et al., 1983; Hassan et al., 1999).

\section{Tapping cost}

The total tapping cost per unit area of high frequency rubber tapping system, $T_{2}$, was the highest during the study period because of high number of tapped trees a day. LFRTS with rainguard, $\mathrm{T}_{5}$, cost $5433 \mathrm{USD} / \mathrm{ha}$ during the year which was $17 \%$ and $39 \%$ lower than that of $\mathrm{T}_{1}$ and $\mathrm{T}_{2}$, respectively (Fig 3 ) because of less number of tapped trees a day in the area and less number of tapper requirement. Regarding the average tapping cost per unit production, the high frequency rubber tapping system, $\mathrm{T}_{2}$, cost higher than that of other treatments. The cost of $\mathrm{T}_{5}$ was $0.29 \mathrm{USD} / \mathrm{kg}$ which was $17 \%$ and 22\% lower than that of $\mathrm{T} 1$ and $\mathrm{T} 2$, respectively (Fig 4) because under LFRTS, its tapper productivity was higher and the number of tappers required was lesser. In Sri Lanka, under LFRTS, S/2 d3, due to higher tapper productivity, the cost of production per unit area could be reduced by $20 \%$ of that of the conventional tapping system, $\mathrm{S} / 2 \mathrm{~d} 2$ (Nugawela et al., 2000). Although there were costs of stimulation, rainguard and fungicide under the LFTS with rainguard, these costs could be compensated easily by its cost saving due to the lower cost of production (Kudaligama et al., 2010; Thomas, 2013).

\section{Materials and Methods}

\section{Location of the experiment}

The experiment was conducted at a rubber estate located at $16.00^{\circ} \mathrm{N}$ and $97.63^{\circ} \mathrm{E}$, and $111 \mathrm{~m}$ of altitude in Thanbyuzayet Township, Mon State, Myanmar. The study was carried from June 2015 to May 2016.

\section{Plant material}

The experiment was conducted on BPM 24 clone planted in 2005 at $3 \mathrm{~m} \mathrm{x} 7 \mathrm{~m}$ spacing on flat land and opened for tapping in 2011. Tapping for the experiment was carried out on virgin bark of second basal panel (BO-2) of the trees at $120 \mathrm{~cm}$ height from the ground.

\section{Experimental design and treatments}

Five treatments of different tapping systems were evaluated with four replications in Randomized Complete Block Design (RCBD). Each plot consisted of 60 trees in 6 rows with 10 trees and the total number of trees conducted was 1200 in 20 plots. The summary of the five treatments are shown in Table 5 .

\section{Installation of the rainguard}

The rainguards were fixed in the second week of May before the starting of the rainy season. Mancozeb fungicide was sprayed on the tapped panel of the trees tapped with the rainguards at weekly interval during the rainy season to prevent panel diseases.

\section{Traits measured}

By using a mini weather station at the experiment site, daily rainfall, cumulative rainfall, raining patterns and number of raining days were identified. Fresh latex from each plot was collected on every tapping day to determine daily rubber yield of every treatment in gram per tapping per tree. Bark consumption measurement was also carried out in the end of May 2016.

Tapper requirement and tapping costs based on unit area and unit production were calculated according to the different tapping systems, their yields resulting from the experiments, and local tapper payment rates and practices resulting from interviews and field surveys. The field surveys were carried out to know the practices of local farmers, and current conventional tapping systems practiced in the area. The tapping costs were calculated for piece work payment system based on number of tapped trees which is the most prevalent tapper payment system in the area.

\section{Statistical analysis}

An analysis of variance was carried out to compare the data of the five treatments including daily yields, cumulative yields and average bark consumptions with Sirichai Statistics 6.00 and Duncan's Multiple Range Test, at $p \leq 0.05$.

\section{Conclusion}

According to the observations on rainfall and raining pattern, regular tapping could not be carried out without rainguard during the rainy season in the area. Under rainguard tapping, $\mathrm{S} / 2 \mathrm{~d} 3$ tapping system is more effective than the conventional tapping system, $\mathrm{S} / 2 \mathrm{~d} 2$, in terms of tappable days during the rainy season. In terms of yield performances, the daily yield of $\mathrm{d} 3$ tapping system was $23 \%$ and $30 \%$ higher than those of $\mathrm{d} 2$ and $2 \mathrm{~d} 3$ tapping systems. With higher tapper productivity throughout the year, the cumulative yield of LFRTS with rainguard was comparable with that of the conventional tapping system, S/2 d2. In addition, its lower bark consumption can prolong the economic lifespan of the tree. In terms of economic performance, the LFRTS with rainguard could reduce $33 \%$ of the tapper requirement of the conventional tapping system and solve the problem of tapper shortage. The tapping costs both based on unit area and unit production of the LFRTS with rainguard were $17 \%$ lower than that of the conventional tapping systems. In conclusion, the study revealed that an optimum yield could be harvested with low cost of production practically throughout the year with potential longer economic lifespan of the tree by implementing the LFRTS with rainguard. It could be a solution to address the problems of the rubber farmers in the high rainfall area of Myanmar. 


\section{Acknowledgement}

Owner and manager from Ye Set Taung Rubber Estate are appreciated for allowing the experiment to be conducted and providing facilities for the experiment. Authors would like to thank also supervisor and tappers who were assigned at the experiment plots. This work was financially supported by Graduate School, Prince of Songkla University, Thailand.

\section{References}

Chan WH, Zainal Abidin MG, Chuah HC (1983) Preliminary results of low intensity tapping systems with stimulation of PR 107 and GT 1. In: Proceedings of Planters' Conference. Rubber Research Institute of Malaysia, Kuala Lumpur, Malaysia, 1983.

d'Auzac J, Jacob JL, Prevot JC, Clement A, Gallois R, Chrestin H, Lacote R, Pujade-renaud V, Gohet E (1997) The regulation of cis-polyisorene production (natural rubber) from Hevea brasiliensis. In: Pandalai SG (ed) Recent research developments in plant physiology. Research Singpost, Trivandrum, India. 273-332.

Gan LT, Chew OK, Ho CY, Wood BJ (1985) Stimulation regimes for reduced tapping intensity on panels BO-1 and BO-2 of RRIM 600, GT 1 and PBIG/GGI seedlings. In: Proceedings of the international rubber conference. Rubber Research Institute of Malaysia, 1985.

Hassan J, Sivakumaran S, Said, MAKM (1999) Economics of low intensity tapping systems. In: Proceedings of the seminar on low intensity tapping systems (LITS). Malaysian Rubber Board, Sungei Buloh, Malaysia, 10 August 1999.

Jacob JL, Prervot JC, Roussel D, Lacrottle R, Serres E, d'Auzac J, Eschbach JM, Omont H (1989) Yield-limiting factors, latex physiological parameters, latex diagnosis and clonal typology. In: d'Auzac J, Jacob JL, Chrestin H (ed) Physiology of rubber tree latex. CRC Press, Boca Raton, Florida. 345-382.

Karunaichamy K, Thomas KU, Rajagopal R (2012) Yield performance of clone RRII 105 under low frequency tapping in BO-2 an in BI-1 panels. Nat Rubber Res. 25: 5260.

Kudaligama KVVS, Rodrigo VHL, Fernando KMEP, Yapa PAJ (2010) Response of low frequency harvesting systems of rubber under drier climatic conditions in Sri Lanka. In: Proceedings of the $15^{\text {th }}$ international forestry and environment symposium, department of forestry and environmental science, University of Sri Jayewardenepura, Sri Lanka, 26-27 November 2010.

Lacote R, Doumbia A, Thaler P, Obouayeba S, Gohet E (2014) Advanced knowledge in latex harvest techniques: relationships between tapping intensity and latex yield. Paper presented at IRRDB workshop on agronomy and plant breeding, Dawei, Myanmar, September 2014.

Mahyao A, Soumahin EF, Koffi C, Coulibaly LF, N'Guessan AEB, Kouame C, Obouayeba (2014) Economic analysis of compensating systems for the scarcity of tapping labour in the rubber industry in Cote d'Ivoire. J Rubber Res. 17(1): 34-44.

Myint H (2015) Overview of rubber planting industry in Myanmar. Paper presented at India rubber meet, Kochi, Kerala, India. 4-5 March 2015.

Nugawela A, Peries MRC, Wijesekera S, Samarasekera RK (2000) Evaluation of d3 tapping with stimulation to alleviate problems related to $\mathrm{d} 2$ tapping of Hevea. J Rubber Res Inst Sri Lanka. 83: 49-61.
Obouayeba S, Soumahin EF, Coulibaly LF (2010) Low intensity tapping systems applied to clone PR 107 of Hevea brasiliensis (Muell. Arg.) in South-eastern Cote d'Ivoire: influence of nature of the exploited bark and the position of tapping panel. Agr Biol J N Am. 1: 1106-1118.

Obouayeba S, Soumahin EF, Okoma KM, Boko AMCK, Dick KE, Lacote R (2011) Relationship between tapping intensity and tapping panel dryness susceptibility of some clones of Hevea brasiliensis in Southwestern Cote d'Ivoire. Agr Biol J N Am 2(8): 1151-1159.

Rodrigo VHL, Kudaligama KVVS, Fernando KMEP, Yapa PAJ (2011) Harvesting the rubber tree once in four days; a solution to current issues in the rubber industry in Sri Lanka. J Rubber Res Inst Sri Lanka. 91: 15-35.

Rodrigo VHL, Kudaligama KVVS, Fernando KMEP, Yapa PAJ (2012) Replacing traditional half spiral cut by a quarter cut with ethephon; a simple approach to solve current issues related to latex harvesting in rubber industry. J Natn Sci Foundation Sri Lanka. 40: 283-291.

Said MAM, Chang K, Tam YC (1998) Rain gutter as an effective tapping and to enhance land productivity: technical aspects. Planters' Bulletin. 2: 14-32

Serres E, Lacrotte R, Prevot JC, Clement A, Commere J, Jacob JL (1994) Metabolic aspects of latex regeneration in situ for three Hevea clones. Indian J Nat Rubber Res. 7: 72 88.

Sivakumaran S, Pakianathan W, Abrahamm D (1982) Longterm ethephon stimulation II: effect of continuous ethephon stimulation with low frequency tapping systems. J Rubber Res Inst Malaysia. 30: 174-196.

Sivakumaran S, Said MAM, Kewi C, Choi TY (1998) Rainfall as a major influencing land productivity in rubber plantation. Planters' Bulletin. 2: 3-13.

Soumahin EF, Obouayeba S, Dick KE, Dogbo DO, Anno AP (2010) Low intensity tapping systems applied to clone PB 217 of Hevea brasiliensis (Muell. Arg.): results of 21 years of exploitation in South-Eastern Cote d'Ivoire. Afr J Plant Sci. 4(5): 145-153.

Thanh DK, Sivakumaran S, Choo AW (1996) Long-term effect of tapping and stimulation frequency on yield performance of rubber clone GT 1. J Nat Rubber Res. 11: 96-107.

Thomas W (2013) The effect of rain guard on reducing latex loss. J Mat Sci Eng A. 3(8): 564-568.

Tillekeratne LM, Nugawela A (1995) Tap rubber boom with rainguard. Rubber Asia, September-October, 1995. 67-75.

Vijayakumar KR, Thomas KU, Rajagopal R, Karunaichamy $K$ (2001) Low frequency tapping systems for reduction in cost of production of natural rubber. Planters' Chronicle. 97(11): 451-454.

Vijayakumar KR, Thomas KU, Rajagopal R, Karunaichamy $\mathrm{K}$ (2003) Advances in exploitation technology and adoption by smallholders. Paper presented at the IRRDB annual symposium, Chaing Mai, Thailand.

Webster CC, Paardekooper E (1989) Exploitation of the rubber tree. In: CC Webster, WJ Baulkwill (ed) Rubber. Longman Scientific and Technical, New York. 345-414.

Yogaratnam N (2013) Rain-guarding technology can boost NR production. Daily Mirror. Available at: http://www.dailymirror.lk/25890/rain-guardingtechnology-can-boost-nr-production. Accessed in February 2013.

Zaw ZN (2012) Tapping in the rainy season. In: Tapping or latex harvesting technology. Myanmar Rubber Planters and Producers Association, Yangon, Myanmar. 33-35. 